\title{
Correction of Platelet Activity in New-Born Calves with Iron Deficit as a Result of Ferroglukin, Polyson and Cresacin
}

\author{
Svetlana Yuryevna Zavalishina and Ilya Nikolaevich Medvedev \\ Kursk Institute of social education (branch) of the Russian State social University, Russia
}

Submission: February 23, 2017; Published: March 03, 2017

"Corresponding author: Ilya Nikolaevich Medvedev, Kursk Institute of social education (branch) of the Russian State social University, 305035, Kursk, Russia, Email: ilmedv1@yandex.ru

Abstract

During our research it was established that new-born calves with iron deficit also have lowering of plasma antioxidant protectability, intensification of lipids' peroxidation processes, increase of thrombocytes' hemostatic activity and blood coagulant system, and at the same time - decrease of vascular wall's ability to bound it. As a result of application of ferroglukin, polyson and cresacin combination to new-born calves with iron deficit we managed to get evident increase of blood plasma antioxidant protectability, significant decrease in it of lipids' peroxidation processes at normalization of thrombocyte activity and positive dynamics of hemostasis vascular and plasma components.

Keywords: New-born calves; Iron deficit; Hemostasis system; Ferroglukin; Polyson; Cresacin

\section{Introduction}

As the state of iron deficit is spread enough among new-born calves [1] and it is rather often accompanied by development of disturbances in hemostasis system [2] there is a great practical demand in their quick and effective removal among calves at farms. At the same time effective approaches aimed at simultaneous reduction of iron deficit and hemostasiopathy signs are still worked out unsatisfactorily [3].

That's why investigations led with new-born calves with the aim of finding approaches to early and effective hemostasiopathy correction on the model of iron deficit state keep their great scientific and practical significance. Worked out at the given state varients of evidence decrease of hemostasis disturbances can serve the basis for the following creation of correction complexes able to be effective in the field of hemostasiopathy reduction of new-born calves at many diseases. Great interest should exist to the evaluation of influence on the whole hemostasis system of the combination of traditionally applied at iron deficit ferroglukin [3], and earlier shown their high biological activity and ability to influence hemostasis system separate components metabolically active means- polyson [4] and cresacin [5].

In this connection we put the following aim for our investigation -to find the evidence of platelets activity correction of new-born calves with iron deficit with the help of ferroglukin, polyson and cresacin combination.

\section{Materials and Methods}

The work was fulfilled with 37 new-born calves having the signs of erythrogenesis and decrease of iron content in their organisms (serum iron $13,1 \pm 0,09 \mathrm{mkmol} / \mathrm{l}$, siderocytes $1,5 \pm 0,05 \%$, ha emoglobin $98,2 \pm 0,25 \mathrm{~g} / \mathrm{l}$, erythrocytes $\left.4,2 \pm 0,18 \times 10^{12} / \mathrm{l}\right)$. The control group contained 29 healthy newborn calves.

The state of lipids' peroxidation (LPO) in animals' plasma was found out according to the quantity in it of thiobarbituric acid-active products with the help of a set by the firm "Agat-Med" (Russia) and acylhydroperoxides with the account of antioxidant activity level of the liquid part of blood [6]. Thrombocytes' number in calves' blood was found out by their calculation in Gorjaev's chamber. Thrombocytes aggregation was registered by visual micro method [7] with some inductors: with ADP (0,5x10 $\left.{ }^{4} \mathrm{M}\right)$, with thrombin $(0,125 \mathrm{un} / \mathrm{ml})$, with collagen (dilution $1: 2$ of the main suspension), with rhystomicin $(0,8 \mathrm{mg} / \mathrm{ml})$, with adrenalin $\left(5 \times 10^{-6} \mathrm{M}\right)$ in plasma with standardized quantity of thrombocytes in it $\left(200 \times 10^{9} \mathrm{tr}\right.$.). 
The correction of iron deficit state of new-born calves was realized by ferroglukin intra muscularly, once from the calculation of $15 \mathrm{mg}$ of iron on $1 \mathrm{~kg}$ of body mass, polyson $5 \mathrm{mg} / \mathrm{kg}$ in the morning in the scheme of liquid feeding during 6 days and cresacin-every day $3 \mathrm{mg} / \mathrm{kg}$ in the scheme of liquid feeding during 6 days beginning simultaneously with ferroglukin application. Evaluation of healthy animals' state was made two times-at their birth and on the $7^{\text {th }}$ day of life. Because of the absence of reliable differences between the results of both investigations control values of each index are presented by one figure-a simple average between them. Examination of calves having iron deficit was fulfilled twice -at their birth and on the next day after correction finish (the $7^{\text {th }}$ day of life). Statistical processing of received data was fulfilled by Student's t-criteria.

\section{Results and Discussion}

Examined new-born calves with iron deficit were found to have characteristic for the given state weakness, limpness, absence of interest to the environment, paleness of rhinoscope and slime layers. These animals were noted to have increased LPO activity in plasma (acylhydroperoxide 3,41 $\pm 0,022$ D233/1ml, thiobarbituric acid-active products $5,20 \pm 0,027 \mathrm{mkmol} / \mathrm{l}$ at value depression of blood liquid part antioxidant activity $22,2 \pm 0,15 \%$ ). The values of these indices under control were equal to $1,45 \pm 0,010 \mathrm{D} 233 / 1 \mathrm{ml}, 3,46 \pm 0,012 \mathrm{mkmol} / \mathrm{l}$ and $33,7 \pm 0,15 \%$ correspondingly.

Table 1: Parameters of hemostasis in newborn calves with iron deficiency treated with ferroglukin, polyson and cresacin. $p$ - reliability of differences of indicators between the control and the initial state of the calves with iron deficiency, p1 - reliability of dynamics of indicators in calves with iron deficiency against the background of correction.

\begin{tabular}{|c|c|c|c|}
\hline Consider Indicators & $\begin{array}{l}\text { Calves with Iron Deficiency } \\
\text { Outcome }\end{array}$ & $\mathbf{N}=37, \mathbf{M} \pm \mathrm{M}$ After the Correction & Control $N=29, M \pm M$ \\
\hline platelet aggregation with ADP, s & $26,0 \pm 0,16$ & $\begin{array}{c}40,1 \pm 0,12 \\
\mathrm{p} 1<0,01\end{array}$ & $\begin{array}{c}40,2 \pm 0,08 \\
\mathrm{p}<0,01\end{array}$ \\
\hline $\begin{array}{l}\text { platelet aggregation with collagen, } \\
\text { s }\end{array}$ & $19,2 \pm 0,21$ & $\begin{array}{c}31,3 \pm 0,08 \\
\mathrm{p} 1<0,01\end{array}$ & $\begin{array}{c}31,4 \pm 0,08 \\
\mathrm{p}<0,01\end{array}$ \\
\hline $\begin{array}{l}\text { platelet aggregation with } \\
\text { thrombin, s }\end{array}$ & $36,5 \pm 0,12$ & $\begin{array}{c}54,2 \pm 0,20 \\
\mathrm{p} 1<0,01\end{array}$ & $\begin{array}{c}53,8 \pm 0,07 \\
\mathrm{p}<0,01\end{array}$ \\
\hline $\begin{array}{l}\text { platelet aggregation with } \\
\text { rystomicin, s }\end{array}$ & $21,0 \pm 0,19$ & $\begin{array}{c}48,1 \pm 0,14 \\
\mathrm{p} 1<0,01\end{array}$ & $\begin{array}{c}48,0 \pm 0,12 \\
\mathrm{p}<0,01\end{array}$ \\
\hline $\begin{array}{l}\text { platelet aggregation with } \\
\text { adrenalin, s }\end{array}$ & $67,9 \pm 0,23$ & $\begin{array}{c}97,4 \pm 0,16 \\
\mathrm{p} 1<0,01\end{array}$ & $\begin{array}{c}97,6 \pm 0,06 \\
\mathrm{p}<0,01\end{array}$ \\
\hline
\end{tabular}

Realization of genetically defined growth and development processes of living organisms takes place at constant influence on organism of numerous factors of environment and internal environment. Physiological peculiarities of their influence are mostly expressed by the optimum of living beings' blood content [8] especially as far as hemostasis system components' activity is concerned [9]. Besides, any disturbances in an organism are accompanied by negative dynamics of hematological indices including parameters of hemostasis system. It becomes clear,
Thrombocytes' quantity in new-born calves' blood corresponded to norms. Besides, thrombocytes' aggregation of animals with iron deficit turned out to be reliably increased (Table 1). Their earliest thrombocytes' aggregation appeared in response to collagen $(19,2 \pm 0,21 \mathrm{~s})$, a bit later it developed with ADP and with rhystomicin, still later in response to thrombin $(36,5 \pm 0,12 \mathrm{~s})$. The latest thrombocytes' aggregation of calves with iron deficit appeared under adrenalin influence $(67,9 \pm 0,23 \mathrm{~s})$.

Realized state correction provided examined calves with iron deficit improvement of the common state and their activity, increase of their serum iron level to the control values $(23,2 \pm 0,21 \mathrm{mkmol} / \mathrm{l})$. On the background of ferroglukin, polyson and cresacin combination examined calves were found to have evident plasma content decrease of acylhydroperoxides $(1,70 \pm 0,014 \mathrm{D} 233 / 1 \mathrm{ml}, \mathrm{p}<0,05)$ and thiobarbituric acid-active products $(3,87 \pm 0,019 \mathrm{mkmol} / \mathrm{l}, \mathrm{p}<0,05)$ at the increase of antioxidant activity to $28,6 \pm 0,16 \%(\mathrm{p}<0,05)$.

Correction realization of animals having at the beginning iron deficit was accompanied by invariability of thrombocytes' quantity in their blood and slowdown of thrombocytes' aggregation to the control level. Besides, most actively animals' thrombocytes responded by aggregation to collagen, ADF and rhystomicin, less actively - to thrombin and adrenalin addition into plasma (Table 1). that in the basis of hemostasiopathy development in case of examined new-born calves we have not only iron deficit but also found during investigation depression of plasma antioxidant defiance which as previous works showed causes LPO activation in it. Increase of peroxidation in plasma damages structures of blood platelets and vessels and affects their functions. Found in new-born calves with iron deficit thrombocytes' aggregation acceleration points at the increase of their receptors' sensibility to stimulating influences from the outside. Besides, active 
development of thrombocytes' aggregation in response to rhystomicin in case of calves with iron deficit should be regarded as consequence of their sensibility increase to Willybrand's factor. Besides, acceleration of thrombocytes' aggregation coming of these animals indirectly tells about the increase in their blood platelets of exchange processes of arachidonic acid with surplus thromboxan A2 formation [10].

Application of ferroglukin, polyson and cresacin combination made new-born calves with iron deficit state feel saturation of their organisms with iron, positive dynamics of red blood and common animals' state indices. Fulfilled impact on examined calves' organisms was accompanied by lowering of their LPO processes intensity in plasma what weakened its damaging influence on endothelium and liver thrombocytes [11]. Found normalization of thrombocytes aggregation of calves with iron deficit state after getting of ferroglukin, polyson and cresacin combination is mostly the consequence of these means combination positive impact on inner thrombocyte LPO, receptor and post receptor thrombocytes' functioning mechanisms. Developing in these conditions time increase of thrombocytes aggregation coming in response to rhystomicin pointed at lowering in these calves' blood of adhesion cofactor Willybrand's factor [12].

\section{Conclusion}

New-born calves having iron deficit are characterized by lowering of blood plasma antioxidant defence, intensification in it of LPO processes, increase of thrombocyte hemostatic activity. With the help of application to new-born calves with iron deficit of the combination of ferroglukin, polyson and cresacin we can really strengenplasma antioxidant defence, weaken LPO activity in it, normalize thrombocyte activity.

\section{References}

1. Yavuz E, Todorov N, Ganchev G, Nedelkov K (2015) The effect of feeding different milk programs on dairy calf growth, health and development. Bulgarian Journal of Agricultural Science 21(2): 384-393.

2. Glagoleva TI (2015) The ability to aggregation of erythrocytes, platelets and white blood cells in the newborn calves. Veterinarian 3: 49-53.

3. Glagoleva TI, Zavalishina S Yu, Medvedev IN (2011) Vascular control of platelet aggregation in the newborn calves with iron deficiency treated ferroglyukin. Modern high technologies 3: 93.

4. Khusainov VR, Fenchenko NG (2005) Polizon Impact on growth of pigs and the quality of their products. Siberian bulletin agricultural nauki 2: 89-93.

5. Guryanov AM, Petunenkov SV, Borin AV, Makarov II (2007) The efficiency of feeding calves and feed additives Natuphoskrezatcina composed of feed. Zootehniya 10: 10-11.

6. Chevari S, Andyal T, Strenger J (1991) Determination of antioxidant blood parameters and their diagnostic value in the elderly. Laboratory work 10: 9-13.

7. Medvedev IN, Savchenko AP, Zavalishina S Yu, Krasnova EG (2009) Methodological approaches to the study of the rheological properties of blood in various states. Russian Journal of Cardiology 5: 42-45.

8. Csilla Tóthová, Nagy Oskar, Kováč Gabriel, Nagyová, Veronika (2016) Changes in the concentrations of serum proteins in calves during the first month of life. Journal of Applied Animal Research 44(1): 338-346.

9. Krasnova EG, Kutafina NV (2015) Fundamentals of platelet functioning. Veterinary Medicine, Animal Science and biotehnologiya 8: 6-18.

10. Simonenko VB, Medvedev IN, Gamolina OV (2011) Primary hemostasis activity in patients with arterial hypertension and impaired glucose tolerance treated with trandolapril. Klin Med (Mosk) 89(2): 29-31.

11.Zavalishina S Yu (2012) Activity of Vascular Hemostasis in Milk-Fed Calves. Russian Agricultural Sciences 38(4): 321-323.

12.Zavalishina S Yu (2012) Hemostatic Activity of Vascular Wall of Newborn Calves. Russian Agricultural Sciences 38(1): 51-54.

\section{Your next submission with Juniper Publishers} will reach you the below assets

- Quality Editorial service

- Swift Peer Review

- Reprints availability

- E-prints Service

- Manuscript Podcast for convenient understanding

- Global attainment for your research

- Manuscript accessibility in different formats

( Pdf, E-pub, Full Text, Audio)

- Unceasing customer service

Track the below URL for one-step submission https://juniperpublishers.com/online-submission.php 